\title{
PERUBAHAN UNSUR-UNSUR SENI PERTUNJUKAN RAKYAT SISINGAAN DI KABUPATEN SUBANG
}

\author{
${ }^{1}$ Cecep Darmawan, ${ }^{2}$ Mirna Nur Alia A, ${ }^{3}$ Anindita Saraswati N \\ ${ }^{1}$ Dosen Prodi Pendidikan Sosiologi, FPIPS Universitas Pendidikan Indonesia \\ ${ }^{2}$ Dosen Prodi Pendidikan Sosiologi, FPIPS Universitas Pendidikan Indonesia \\ ${ }^{3}$ Mahasiswa Prodi Pendidikan Sosiologi \\ E-mail : cecepdarmawan@upi.edu
}

\begin{abstract}
ABSTRAK
Adanya perubahan-perubahan yang terjadi pada seni pertunjukan rakyat sisingaan yang dipengaruhi oleh perkembangan zaman. Terdapat perubahan pada unsur-unsur seni pertunjukan rakyat sisingaan yang mengarah pada perkembangan seperti unsur seni rupa dan busana pengusung yang dibuat semakin menarik dengan warna-warna yang cerah, unsur widitra (karawitan) dan sinden yang dikolaborasikan dengan alat musik modern seperti gitar dan bass, serta unsur gerak tari yang semakin kreatif dan seringkali dipadukan dengan atraksi yang dapat menghibur para penonton. Penelitian ini merupakan penelitian kualitatif dengan metode studi kasus ditinjau dari lingkup wilayahnya merupakan penelitian kasus yang hanya meliputi wilayah yang sempit namun dapat menggali lebih mendalam. Subjek penelitian ini ada kelompok seniman sisingaan Putra Jamparing Group yang berlokasi di Blok Cibogo, RT. 25/ RW. 06 Nomor 37 Kelurahan Dangdeur, Kecamatan Subang, Kabupaten Subang. Kelompok seniman sisingaan Putra Jamparing Group merupakan kelompok seniman sisingaan yang telah berdiri sejak tahun 1997 dan hingga saat ini masih bertahan menjaga eksistensinya.
\end{abstract}

Kata Kunci: Perubahan Sosial dan Budaya, Seni Pertunjukan Rakyat Sisingaan.

\section{PENDAHULUAN}

Manusia merupakan mahluk berbudaya yang memiliki daya cipta, rasa dan karsa. Setiap hari manusia selalu bersentuhan dengan kebudayaan yang diciptakan olehnya di dalam masyarakat. Budaya yang tercipta adalah suatu cara hidup yang berkembang dan dimiliki bersama oleh sebuah kelompok orang dan diwariskan dari generasi ke generasi yang dimaksudkan untuk melestarikanya. Budaya dapat menjadi salah satu pemersatu dalam bermasyarakat. Melalui kebudayaan dapat menampilkan identitas dari masyarakat, yang akan berbeda antara masyarakat satu dan yang lain. Fungsi dari kebudayaan sangat besar bagi manusia dan masyarakat. Dalam kehidupan masyarakat memiliki kebutuhan-kebutuhan yang begitu kompleks, baik kebutuhan spiritual maupun materiil. Kebutuhankebutuhan tersebut untuk sebagian besar dipenuhi oleh kebudayaan yang 
bersumber pada masyarakat itu sendiri.

Salah satu dari bentuk kebudayaan adalah kesenian, dimana dalam kesenian memuat beberapa unsur dari kebudayaan yang membentuknya. Menurut Koentjaraningrat (1990, hlm. 50) bahwa kesenian merupakan hasil ciptaan dari segala pikiran dan perilaku manusia yang fungsional, estetis dan indah, sehingga ia dapat dinikmati dengan panca inderanya yaitu penglihatan, penciuman, pengecap, perasa, dan pendengaran yang dimiliki oleh manusia.

Indonesia

dengan

keanekaragaman budaya yang melengkapinya menjadi suatu identitas bangsa yang penting untuk diwarisi oleh para generasi penerus. Seperti yang diungkapkan oleh Koentjaraningrat (1990, hlm. 50)

Kesenian yang merupakan salah satu unsur kebudayaan universal, merupakan unsur yang dapat menonjolkan sifat, khas dan mulutnya, dengan demikian kesenian merupakan unsur yang paling utama dalam kebudayaan nasional indonesia.

Oleh karena itu usaha-usaha dalam pewarisan ini menjadi hal yang perlu dilakukan. Usaha-usaha ini banyak dilakukan oleh para seniman seni pertunjukan rakyat yang pada umumnya sederhana dan mudah dimengerti oleh masyarakat. Kelebihan utama lainnya dari seni pertunjukan rakyat adalah karena apa yang dipertontonkan telah menjadi bagian dan lekat dengan kehidupan masyarakat, sehingga makna 'yang tersirat menjadi mudah dimengerti oleh masyarakat yang menontonnya.

Setiap daerah memiliki kesenian masing-masing yang dapat dijadikan ikon atau ciri khas dari suatu daerah. Dari kesenian tersebut terkandung nilai sejarah, pesan moral, ajaran serta norma yang berlaku di lingkungan masyarakatnya. Tidak jarang kita menemukan kesenian yang menjadi filosofis kehidupan dari suatu masyarakat yang memiliki nilai tinggi khususnya seni tradisi. Kesenian juga dapat memiliki nilai ekonomi ketika kesenian tersebut dijadikan seni pertunjukan sehingga akan mendatangkan keuntungan bagi para pelaku dan pegiat dari kesenian tersebut.

Kota Subang adalah salah satu kabupaten di provinsi Jawa Barat. Kabupaten ini dilintasi oleh jalur pantura, dimana jalur tersebut merupakan jalur yang paling sibuk di Pulau Jawa. Kabupaten Subang memiliki kesenian lokal yang cukup beragam yang didukung oleh keadaan masyarakat dan batas wilayah administratif. Kesenian yang terdapat di Subang antara lain Gotong Singa atau lebih dikenal dengan sebutan seni pertunjukan rakyat Sisingaan.

Keseniaan

Sisingaan

merupakan salah satu kesenian daerah yang sampai sekarang masih berkembang dengan baik di daerah Subang. Kesenian Sisingaan telah dimainkan oleh rakyat Subang pada saat melawan penjajahan dulu sebagai simbol pelecehan terhadap penjajah, yang pada waktu itu adalah negara agraris. Dimana lambang negara itu adalah Singa atau Negara yang ditakuti yang dinaiki oleh seorang anak kecil diatas punggungnya yang melambangkan bahwa rakyat Subang tidak takut melawan penjajahan pada saat itu. Namun, modifikasi budaya yang terjadi pada seni pertunjukan rakyat Sisingaan ini dikhawatirkan akan 
merubah atau mengganti makna dari kesenian ini dimata masyarakat penikmatnya, khususnya masyarakat Subang.

Sisingaan merupakan salah satu seni pertunjukan rakyat Jawa Barat, khas Subang yang berupa pertunjukan keterampilan memainkan tandu berisi boneka singa. Dalam perkembangannya, bentuk singa semakin disempurnakan. Demikian juga kostum, gerak tari, dan juga musik pengiringnya yang semakin disempurnakan. Penyempurnaan pada seni pertunjukan rakyat Sisingaan membuat perubahanperubahan terjadi pada penyajian seni pertunjukan rakyat Sisingaan.

Berkaitan dengan perubahanperubahan yang ada pada seni pertunjukan rakyat sisingaan untuk terus memelihara dan mengembangkan seni perttunjukan rakyat tersebut di tengah-tengah masyarakat Subang, penulis mencoba mengkaji perubahan-perubahan khususnya unsur-unsur yang ada pada penyajian seni pertunjukan rakyat Sisingaan seperti unsur seni rupa dan busana pengusung, unsur widitra (karawitan) dan sinden, serta unsur gerak tari.

Akulturasi budaya memang tidak bisa dihindari selama masih menjaga nilai dan norma didalamnya. Berdasarkan ungkapan Bisri Mustofa dalam Kamus Lengkap Sosiologi karya Mustofa (2010, hlm. 12) berpendapat bahwa "Akulturasi adalah proses pertemuan unsur-unsur dari pelbagai kebudayaan yang berbeda, yang diikuti dengan percampuran unsur-unsur tersebut. Perbedaan antara unsur-unsur asing dengan yang asli, masih nampak".

Begitu pula dengan Sisingaan, di dalam

perkembangannya berakulturasi baik dalam bentuk singanya yang dibuat dengan sangat menarik, ataupun dari segi pakaian pengusung, serta lagu-lagu yang disindenkan. Selain itu pada bagian musik pengiringnya ada pula yang ditambah dengan instrumental musik modern seperti guitar, keyboard dan lain-lain. Sehingga menjadi memiliki daya tarik tersendiri dan mampu diterima pementasannya oleh semua kalangan. Namun orisinalitas seni tradisi sisingaan harus juga diperhatikan oleh para sanggar seni yang memberikan jasa pertunjukan itu. Dengan diterimanya seni pertunjukan sisingaan ini dapat dilihat dari banyaknya pemakai jasa seni pertunjukan ini setiap kali ada acara khitanan atau peringatan Maulud Nabi Muhammad SAW, sehingga banyak para pelaku seni berlomba-lomba mendirikan sanggar seni sisingaan. Secara tidak langsung seni pertunjukan sisingaan ini mendongkrak angka kesejahteraan dikalangan seniman itu sendiri.

Salah satu kelompok seniman Sisingaan yang terkenal di Kabupaten Subang adalah kelompok seniman Sisingaan Putra Jamparing Group Subang yang beralamat di Padepokan Putra Jamparing Blok Cibogo, RT. 25/ RW. 06 Nomor 37 Kelurahan Dangdeur, Kecamatan Subang, Kabupaten Subang. Putra Jamparing Group merupakan salah satu kelompok kesenian Sisingaan yang telah lama berdiri dan telah berpengalaman dalam melestarikan kesenian sisingaan dengan melakukan kegiatan hiburan seni pertunjukan rakyat kesenian Sisingaan. Putra Jamparing Group juga merupakan peraih juara ke 1 pada Festival Sisingaan Tingkat Kabupaten Subang pada tahun 2001. 
Pada zaman dahulu seni pertunjukan rakyat Sisingaan dibuat dengan sangat sederhana, gerakan para penarinya pun masih sangat sederhana dan dilakukan secara spontan. Saat ini seni pertunjukan rakyat Sisingaan sudah sangat dikenal, tidak hanya di daerah Subang saja. Di daerah sekitar kabupaten Subang pun bermunculan kelompok seniman Sisingaan. Kabupaten Subang sebagai daerah asal Sisingaan sangat gencar dalam mempromosikan kesenian ini.

Pada masa kini, seni pertunjukan rakyat Sisingaan lebih diartikan sebagai bagian dari hiburan rakyat. Seni pertunjukan rakyat Sisingaan umumnya dipentaskan dengan berkeliling kampung pada saat ada hajatan warga seperti acara khitanan, pelantikan pejabat desa, pernikahan dan acara-acara lainnya.

Seni pertunjukan rakyat Sisingaan yang saat ini sudah diterima oleh masyarakat lokal, nasional bahkan internasional semakin rentan dengan assimilasi dan hilangnya nilai orisinalitas dari Sisingaan itu sendiri sehingga para pelaku seni ini harus mendorong pada pelestarian nilai filosofisnya dengan cara mempertunjukan seni pertunjukan rakyat Sisingaan yang asli dari warisan kokolot Subang.

Ada beberapa alasan pokok mengapa penulis tertarik untuk mengkaji Perubahan Unsur-Unsur SeniPertunjukan Rakyat Sisingaan Subang pada kelompok seniman Sisingaan Putra Jamparing Group di Kabupaten Subang, antara lain :

1. Seni pertunjukan rakyat Sisingaan merupakan seni pertunjukan rakyat tradisional yang harus dilestarikan. Telah banyak bermunculan kelompok seniman Sisingaan yang berkembang salah satunya kelompok seniman Sisingaan Putra Jamparing Group di Kabupaten Subang, namun perubahan-perubahan yang terjadi pada seni pertunjukan rakyat sisingaan ini dikhawatirkan mempengaruhi orisinalitas kesenian ini. Melihat perkembangan yang terjadi, penelitian ini diharapkan sebagai salah satu cara untuk tetap melestarikan kesenian tradisional.

2. Pada penelitian ini penulis ingin mengkaji apa saja perubahanPerubahan Unsur-Unsur Senipertunjukan rakyat Sisingaan pada kelompok seniman Sisingaan Putra Jamparing Group di Kabupaten Subang. Aspek yang ingin dikaji khususnya unsur-unsur yang ada pada penyajian seni pertunjukan rakyat Sisingaan seperti unsur seni rupa dan busana pengusung, unsur widitra (karawitan) dan sinden, serta unsur gerak tari.

3. Dengan adanya penelitian ini diharapkan dapat memberikan pengetahuan baru kepada generasi muda tentang seni pertunjukan rakyat Sisingaan pada kelompok seniman Sisingaan Putra Jamparing Group di Kabupaten Subang yang merupakan salah satu kelompok seniman Sisingaan yang berperan dalam melestarikan kesenian tradisional di Kabupaten Subang, apalagi seni pertunjukan rakyat Sisingaan merupakan kesenian sunda 
khas Subang yang perlu dijaga kelestariannya.

Berdasarkan latar belakang diatas penulis mencoba untuk melakukan penelitian di daerah Subang, dengan menggali informasi mengenai perubahan-perubahan yang terjadi pada seni pertunjukan rakyat Sisingaan khususnya unsurunsur yang ada pada penyajian seni pertunjukan rakyat Sisingaan seperti unsur seni rupa dan busana pengusung, unsur widitra (karawitan) dan sinden, serta unsur gerak tari.

\section{METODE}

Metode yang digunakan dalam penelitian dengan judul "Perubahan Unsur-Unsur Seni Pertunjukan Rakyat Sisingaan Subang (Studi Kasus pada Seniman Sisingaan Putra Jamparing Group di Kabupaten Subang, Jawa Barat)" adalah studi kasus. Menurut Arikunto (2006, hlm. 215) metode studi kasus apabila ditinjau dari lingkup wilayahnya, penelitian kasus hanya meliputi wilayah yang sempit, tetapi ditinjau dari sifat penelitiannya, penelitian studi kasus ini dapat menggali lebih mendalam dan dapat pula digunakan untuk memecahkan masalah yang aktual dengan mengumpulkan data, menyusunnya, mengklasifikasikannya, kemudian menginterpretasikannya.

Dengan menggunakan metode penelitian studi kasus diharapkan dapat memaksimalkan penelitian yang dilakukan oleh peneliti. Yaitu, mengumpulkan data, menyusun, mengklasifikasikan, kemudian menginterpretasikan data-data yang didapat dalam penelitian dengan judul "Perubahan Unsur-Unsur Seni Pertunjukan Rakyat Sisingaan Subang (Studi Kasus pada Seniman
Sisingaan Putra Jamparing Group di Kabupaten Subang, Jawa Barat)".

Sesuai dengan metode studi kasus yang mana dalam penelitian ini dilakukan untuk penelitian yang meliputi subjek yang khas, yaitu subjek yang belum tentu ada di tempat lain. Sesuai dengan penelitian dengan judul "Perubahan Unsur-Unsur Seni Pertunjukan Rakyat Sisingaan Subang (Studi Kasus pada Seniman Sisingaan Putra Jamparing Group di Kabupaten Subang, Jawa Barat)", subjek dan objek penelitian ini hanya terdapat di Seniman Sisingaan Putra Jamparing Group Kabupaten Subang. Sehingga metode penelitian yang paling cocok adalah metode penelitian studi kasus.

\section{HASIL DAN PEMBAHASAN}

Seni Pertunjukan Rakyat Sisingaan Putra Jamparing Group Pada Awal Terbentuknya Putra Jamparing Group

Selama terbentuknya Putra Jamparing Group, seni pertunjukan rakyat sisingaan merupakan kesenian yang mengangkat nama Putra jamparing dan membawa Putra Jamparing untuk tampil di berbagai acara di berbagai daerah. Selain itu Putra Jamparing juga mendapatkan banyak penghargaan untuk prestasinya dalam melestarikan dan mengembangkan seni pertunjukan rakyat sisingaan.

Pada awal terbentuknya Putra Jamparing Group memiliki Padepokan sebagai tempat segala kegiatan yang dilakukan oleh Putra Jamparing Group seperti latihan dan berkumpul. $\mathrm{Di}$ padepokan ini pula para anggota Putra Jamparing Group berlatih dan membuat gerakan baru untuk lebih mengembangkan seni pertunjukan rakyat sisingaan agar tetap dapat 
digemari dan mampu bersaing dengan kelompok seniman sisingaan lainnya yang banyak bermunculan di Kabupaten Subang. Dahulu di padepokan Putra Jamparing Group juga dijadikan tempat berlatih untuk sisingaan mini. Sisingaan mini merupakan sisingaan yang dimainkan oleh anak-anak laki-laki. Melalui sisingaan mini ini Putra jamparing Group sekaligus melakukan regenerasi untuk penerus pemain seni pertunjukan rakyat sisingaan, sehingga diharapkan dapat meneruskan melestarikan seni pertunjukan rakyat sisingaan dikemudian hari. Namun, saat ini padepokan Putra jamparing telah tidak difungsikan lagi. Hal ini dikarenakan berbagai hal diantaranya keterbatasan dana sehingga padepokan Putra Jamparing Group saat ini berlokasi di kediaman sang pendirinya yaitu di rumah Bapak Mumuk Kertamukti.

Dalam seni pertunjukan rakyat sisingaan ini terdapat beberapa unsur yang menjadikannya suatu kesatuan sajian seni pertunjukan yang dapat menghibur masyarakat Kabupaten Subang dan setiap masyarakat yang menontonnya.

Unsur-unsur pembentuk seni pertunjukan rakyat sisingaan yaitu unsur seni rupa dan busana pengusung, unsur widitra (karawitan) dan sinden, serta unsur gerak tari.

Pakaian yang digunakan dalam seni pertunjukan rakyat sisingaan merupakan baju khas sunda. Pakaian atau busana ini biasanya dipakai oleh seluruh pemain seni pertunjukan rakyat sisingaan. Pemain seni pertunjukan rakyat sisingaan tersebut antara lain pengusung sisingaan dan penabuh alat karawitan. Busana yang dipakai yaitu baju kampret, celana pangsi, iket, ikat pinggang, sepatu, dan kaos kaki.

Sebagai penunjang unsur widitra dan sinden kelompok seniman sisingaan Putra Jamparing Group menggunakan toa sebagai pengeras suara agar suara musik yang dihasilkan dapat didengar oleh penonton dengan jelas. Dengan adanya pengeras suara ini membuat hiburan seni pertunjukan rakyat sisingaan menjadi lebih semarak lagi. Tidak jarang para penonton ikut berjoget dan ikut menari saat menonton seni pertunjukan rakyat sisingaan ini.

Sementara itu lagu-lagu yang dinyanyikan pada masa itu adalah lagu-lagu tradisional sunda. Lagu-lagu yang dinyanyikan oleh sinden pada seni pertunjukan rakyat sisingaan pada awal terbentuknya antara lain lagu badud samping butut, manuk hideung, sireum beureum, dan untuk lagu-lagu pembuka biasanya ditampilkan lagu tunggul kawung. Lagu-lagu tersebut dinyanyikan oleh sinden yang menjadi bagian dari anggota seni pertunjukan rakyat sisingaan yang tampil menghibur dalam suatu acara. Pada awal terbentuknya Putra Jamparing, dalam setiap tampil hanya membawa 1 orang sinden saja untuk menyanyi musik pengiring sisingaan.

Struktur seni pertunjukan rakyat sisingaan yang ditampilkan pada seniman sisingaan Putra Jamparing Group berbeda-beda pada setiap acara yang sedang berlangsung. Seni pertunjukan rakyat Sisingaan yang ditampilkan pada acara Sunatan atau khitanan anak akan berbeda dengan seni pertunjukan rakyat sisingaan yang ditampilkan pada acara pernikahan atau festival. Pada acara sunatan atau khitanan anak seni 
pertunjukan rakyat sisingaan yang ditampilkan akan seperti ini:

a) Pada acara sunatan atau khitanan akan dimualai dengan tahap persiapan yaitu mendandani anak yang disunat dengan pakaian adat sunda. Kostum yang dipakai oleh anak bebas dipilih oleh anak maupun orangtua dari anak seperti memilih baju koko, baju tokoh seperti gatot kaca, baju adat sunda, atau baju sehari-hari juga diperbolehkan sesuai permintaan saja.

b) Kedua adalah sambutan yang di berikan oleh pihak keluaga atau orang yang diwakilkan untuk memberikan sambutan kepada tamu-tamu yang hadir.

c) Ketiga adalah pembuka. Pada bagian pembuka seni pertunjukan rakyat sisingaan ini akan dimainkan lagu pembuka yaitu lagu Kembang gadung atau kidung yang memiliki filosofi tersendiri bagi masyarakat Sunda. Kidung tersebut merupakan lagu yang memiliki lirik yang mengandung arti permohonan keselamatan dan kelancaran saat penampilan seni pertunjukan rakyat sisingaan. Hal tersebut tidak lepas dari faktor bahwa seni pertunjukan rakyat sisingaan ini merupakan pertunjukan dengan mengarak boneka mirip singa yang di atasnya ditunggangi oleh seseorang, sehingga diperlukan kehati-hatian dalam setiap pertunjukannya. Melalui Kidung inilah para seniman sisingaan yang akan tampil meminta izin, memohon keselamatan juga kelancaran dalam pertunjukan yang akan dimainkan. Menurut penuturan Bapak Mumuk Setyamukti permintaan izin dan permohonan keselamstsn ysng terkandung pada Kidung ditujukan kepada Tuhan Yang Maha Esa dan juga kepada para leluhur.

d) Keempat yaitu gerakan galuraan. Yaitu gerakan-gerakan yang dimainkan oleh para seniman sisingaan yang tampil sambil menggotong boneka sisingaan. Boneka sisingaan tersebut biasanya digotong oleh 4 orang seniman sisingaan dan pada galuraan ini seniman tersebut melakukan gerakangerakan tarian yang telah dikreasi sendiri. Gerakan galuraan ini merupakan bentuk kreativitas dari setiap seniman sisingaan sehingga akan berbeda satu dan lainnya. Gerakan khas dari kelompok seniman sisingaan Putra Jamparing Group ini adalah gerakan seperti singa yang sedang merangkak namun gerakan-gerakan ciptaan Putra Jamparing ini kadang juga dipakai oleh kelompok lain. Pada gerakan galuraan akan diiringi oleh musik Ewad dan Gondang. Setelah gerakan-gerakan tersebut ditampilakan maka anak yang akan disunat akan dinaikan ke atas sisingaan dengan dipayungi dengan properti payung adat. Setelah anak yang disunat naik maka akan diarak keliling desa dengan diiringi musik bebas yang dapat direquest oleh pihak keluarga.

e) Tahap terakhir adalah penutup dimana acara arak-arakan selesai dan sisingaan telah kembali ke rute awal. Anak yang 
akan disunat kemudian diturunkan. Para seniman sisingaan kemudian melakukan gerakan-gerakan kreasi dengan diiringi musik penutup yaitu Mitra.

\section{Seni Pertunjukan Rakyat Sisingaan Putra Jamparing Group Pada Saat Ini Setelah Mengalami Perubahan}

Seiring dengan berjalannya waktu, para seniman sisingaan dan para pengrajin boneka sisingaan semakin kreatif dalam memebuat boneka sisingaan yang digunakan dalam seni pertunjukan rakyat sisingaan. Bentuk patung sisingaan semakin dibuat mirip dengan aslinya. Boneka sisingaan saat ini menggunakan bahan bulu yang digunakan untuk membuat boneka sehingga bahannya halus dan membuat boneka sisingaan menjadi semakin mirip dengan singa asli. Dengan penggunaan bahan boneka ini membuat boneka sisingaan menjadi lebih awet dan nyaman saat dinaiki oleh orang. Selain itu, pada boneka sisingaan juga diberi sebuah bantalan sebagai alas bagi orang yang menaiki sisingaan. Penambahan bantalan ini semakin membuat boneka sisingaan ini nyaman untuk dinaiki.

Selain penggunaan bahan untuk membuat boneka, saat ini muka boneka sisingaan juga dibuat lebih variatif lagi melalui ekspresi sisingaan yang dibuat menganga dan memperlihatkan taringnya sehingaa didapatkan kesan singa yang gagah dan garang. Selain itu warna sisingaan juga ada yang dibuat lebih terang dengan memilih bahan bulu berwarna agak kuning keemasan sebagai bahan pembuat boneka sisingaan dimana dahulu hanya menggunakan warna coklat muda yang kurang terang. Dengan menggunakan warna coklat keemasan menjadikan boneka sisingaan lebih cerah dan menarik untuk dilihat.

Seiring dengan berkembangnya zaman unsur tata rias dan busana yang digunakan oleh kelompok seniman Putra Jamparing Group ini semakin berkembang kearah yang lebih baik. Tata rias dan busana pengusung yang digunakan sudah memperhitungkan nilai estetisnya. Sehingga pemilihan tata rias dan busana pengusung ini semakin menarik dan lebih beragam lagi. Hal tersebut dibuktikan dengan penggunaan make up atau riasan bagi para pemain sisingaan. Selain itu juga penggunaan busana seperti baju kampret, celana pangsi, iket, ikat pinggang, sepatu, dan kaos kaki yang digunakan oleh para pengusung sisingaan maupun penabuh alat karawitan yang dibuat seragam sehingga lebih memenuhi unsur estetika dalam seni pertunjukan rakyat sisingaan. Saat ini Putra Jamparing memiliki kurang lebih 4 set busana yang digunakan dalam penampilan seni pertunjukan rakyat sisingaan. 4 set busanan sisingaan ini terdiri dari beberapa warna yang berebeda sehingga dapat dikombinasikan dan berganti-ganti warna saat dipakai. Pada awalnya Putra Jamparing hanya memiliki 1 jenis busana sisingaan saja, yaitu warna kuning yang dikombinasikan dengan warna hijau. Warna busana ini pula yang dijadikan ciri khas busana yang dipakai oleh Putra Jamparing Group dengan kelompok-kelompok seniman sisingaan lain. Dengan banyaknya kelompok seniman sisingaan yang ada di Kabupaten Subang, maka 
setiap kelompok seniman sisingaan berlomba-lomba dalam membuat ciri khas tersendiri agar mudah dikenali dan diingat oleh penggemar seni pertunjukan rakyat sisingaan. Banyaknya kelompok seniman sisingaan yang ada di Kabupaten Subang memicu para seniman sisingaan untuk lebih kreatif dan mengembangkan seni pertunjukan rakyat sisingaan yang dimainkannya.

Musik merupakan salah satu unsur pendukung yang semakin menyemarakan seni pertunjukan rakyat sisingan Putra Jamparing Group. Dengan adanya musik akan membuat seni pertunjukan rakyat sisingaan yang ditampilkan menjadi lebih menarik dan semarak. Oleh karena itu, musik yang digunakan sebagai pengiring dalam seni pertunjukan rakyat sisingaan oleh Putra Jamparing Group saat ini disesuaikan dengan yang digemari oleh masyarakat. Salah satu musik yang sangat digemari oleh masyarakat Indonesia adalah musik dangdut. Begitu pula masayarakat Subang, sebagian besar menaruh minat terhadap musik dangdut sebagai musik yang digemari oleh hampir seluruh lapisan masyarakat. Dengan begitu, para seniman sisingaan mulai menghadirkan musikmusik dangdut sebagai pengiring dalam seni pertunjukan rakyat sisingaan. Putra Jamparing juga menerima segala jenis permintaan musik yang diinginkan oleh si empunya hajat, mulai dari musik tradisional sunda, musik dangdut, dan musik pop dapat disesuaikan dengan permintaan oleh pelanggannya.

Guna menunjang penampilan seni pertunjukan rakyat sisingaan, kelompok seniman sisingaan Putra Jamparing Group juga menyediakan sebuah kereta yang digunakan untuk para sinden dan pemain alat musik. Dengan menggunakan kereta ini mempermudah para pemain alat musik dan sinden untuk memainkan musiknya sehingga tidak perlu lagi berjalan dengan membawa alat-alat musik yang berat. Kereta musik ini berisikan para pemain alat musik dan sinden, selain itu kereta ini juga berisi alat-alat penunjang unsur karawitan dan sinden lainnya seperti pengeras suara atau sound system dan gen-set. Kereta ini juga mempermudah saat seni pertunjukan rakyat Putra Jamparing Group melangsungkan arak-arakan pada saat tampil karena kereta ini menggunakan roda yang dirancang agar mudah untuk didorong sehingga lebih fleksibel dan mudah.

Pada saat ini susunan gerak yang dimainkan oleh Putra Jamparing Group dapat disesuaikan dengan permintaan pelanggan. Biasanya apabila tampil diacara khitanan biasa Putra Jamparing Group sering diminta tampil tanpa menggunakan atraksi. Hal tersebut bisa saja karena Putra Jamparing Group membebaskan para pelanggannya untuk memilih seperti apa pertunjukan sisingaan yang diinginkan dan dapat disesuaikan dengan budget yang dimiliki. Selain susunan pertunjukan yang mengikuti permintaan pelanggan, Putra Jamparing Group juga lebih berinovasi pada gerakan-gerakan yang ditampilkan pada seni pertunjukan sisingaan. Inovasi yang dilakukan yaitu dengan mengkombinasikan gerakan-gerakan silat dan jaipongan yang dipadukan dalam seni pertunjukan rakyat sisingaan. Hal tersebut karena seni pertunjukan rakyat sisingaan ini merupakan kesenian kreasi yang 
dapat dikembangkan melalui kreativitas para seniman sisingaan.

Melestarikan suatu kebudayaan lokal tradisional suatu daerah memiliki tantangan-tantangan yang harus dihadapi. Tantangan-tantangan tersebut adalah berkaitan dengan perkembangan zaman yang menjadi sebuah keniscayaan dalam suatu masyarakat. Perkembangan zaman yang terjadi akan diiringi dengan kemajuan teknologi dan ilmu pengetahuan pada masyarakat. Hal ini memicu tergesernya kebudayaan tradisional yang ada di masyarakat.

Untuk menanggulangi hal tersebut Putra Jamparing mengupayakan untuk tetap dapat melestarikan seni pertunjukan rakyat sisingaan agar tetap memiliki pamor di daerahnya sendiri yaitu di Kabupaten Subang. Salah satu upaya yang dilakukan adalah dengan mengombinasikan unsur-unsur seni pertunjukan rakyat sisingaan dengan teknologi modern dan mengreasikannya menjadi lebih menarik dan kreatif agar tetap digemari oleh masyarakat.

Usaha pelestarian yang dilakukan oleh Putra Jamparing Group akan menjadi sia-sia apabila tidak dilakukan regenerasi untuk menyiapkan penerus seniman sisingaan yang akan meneruskan usaha para seniman sisingaan untuk melestarikan salah satu budaya tradisional Kabupaten Subang ini. Regenerasi amat penting dilakukan untuk menyiapkan generasi-generasi penerus seniman sisingaan. Ini merupakan hal penting yang harus dilakukan oleh setiap kelompok seniman sisingaan dan juga melalui dukungan yang diberikan oleh warga dan pemerintah Kabupaten Subang.
Perubahan Unsur Seni Rupa dan Busana Pengusung pada Seni Pertunjukan Rakyat Sisingaan Putra Jamparing Group

Unsur seni rupa dan busana pengusung merupakan salah satu unsur pembentuk seni pertunjukan rakyat sisingaan yang menunjang dalam penampilan seni pertunjukan rakyat sisingaan.seni rupa pada seni pertunjukan rakyat sisingaan adalah boneka sisingaan yang merupakan ikon dari seni pertunjukan rakyat sisingaan itu sendiri. Sedangkan busana pengusung merupakan busana yang dipakai oleh para pemain sisingaan yang identik dengan warna cerah dan mencolok agar menarik dilihat. Baju pengusung ini berupa baju kampret, celana pangsi, dan sebagai pelengkap menggunakan iket, ikat pinggang, sepatu, dan kaos kaki panjang, Unsur seni rupa dan busana pengusung yang ada pada Putra Jamparing Group di awal-awal terbentuknya masih sangat sederhana. Pertama kali Putra Jamparing Group menggunakan tali rafia dan kayu yang dibentuk seperti seekor singa. Penggunaan rafia dinilai kurang awet dan tidak memenuhi unsur estetis sehingga kemudian diganti dengan benang woll yang digunakan untuk membentuk rambut singa, sedangkan badan boneka singa menggunakan kayu yang diwarnai dengan cat kayu. Saat ini boneka singa dibuat lebih estetis dengan bahan-bahan yang digunakan untuk membuat boneka sehingga lebih nyaman dan semakin mirip dengan aslinya. Busana yang dipakai juga semakin beragam warnanya. Saat ini busana pengusung yang digunakan tidak hanya sekedar untuk kostum tampil namun, Putra Jamparing Group memiliki banyak 
kostum yang dapat disewakan dan dapat berganti-ganti warna saat tampil.

\section{Perubahan Unsur Widitra (Karawitan) dan Sinden pada Seni Pertunjukan Rakyat Sisingaan Putra Jamparing Group}

Unsur widitra atau karawitan dan sinden ini berkaitan dengan musik yang dimainkan oleh pemain musik pada saat penampilan seni pertunjukan rakyat sisingaan. Dengan adanya musik pengiring ini akan membuat seni pertunjukan rakyat sisingaan yang ditampilkan menjadi semakin semarak dan menarik antusias masyarakat untuk menonton. Dalam perkembangannya unsur widitra (karawitan) dan sinden ini dikembangkan dengan memadukan alat musik tradisional dan modern. Selain itu lagu-lagu yang dinyanyikan juga semakin beragam dan menyesuaikan dengan minat musik yang dimiliki oleh masyarakat.

Unsur widitra (karawitan) dan sinden yang ada pada Putra Jamparing Group di awal-awal terbentuknya masih sangat sederhana, karena menggunakan alat-alat tradisional. Alat musik yang digunakan masih tradisional dan menggunakan toa sebagai pengeras suara. Saat ini Putra Jamparing telah semakin modern dengan menggunakan kereta musik yang dilengkapi dengan sound system. Alat musik modern seperti guitar listrik dan bass juga dikombinasikan dengan alat musik tradisional. Lagu yang dinyanyikan oleh sinden tidak terbatas pada lagu tradisional saja namun juga lagu modern seperti lagu dangdut, pop, dan lain-lain.

\section{Perubahan Unsur Gerak Tari pada Seni Pertunjukan Rakyat Sisingaan Putra Jamparing Group}

Unsur gerak tari yang ada pada seni pertunjukan rakyat sisingaan Putra Jamparing Group pada saat ini sudah semakin kreatif. Selain atraksi yang semakin variatif juga terdapat kombinasi gerakan jaipongan pada pertunjukan sisingaa Putra Jamparing Group. Atraksi-atraksi yang dilakukan semakin menarik penonton sehingga tertarik untuk menyaksikan seni pertunjukan rakyat sisingaan yang ditampilkan. Melalui inovasi dan kreasi yang dilakukan oleh Putra Jamparing Group ini diharapkan mampu bersaing dengan seni pertunjukan rakyat sisingaan yang ditampilkan oleh kelompok seniman sisingaan lainnya. Selain itu inovasi dan kreasi yang dilakukan juga dijadikan ciri khas bagi Putra Jamparing Group.

\section{SIMPULAN}

Berdasarkan hasil pembahasan yang telah dipaparkan pada bab sebelumnya oleh peneliti, maka secara umum dapat disimpulkan bahwa terdapat beberapa perubahan yang terjadi pada seni pertunjukan rakyat sisingaan yang ditampilkan oleh Putra Jamparing Group. Terjadinya perubahan-perubahan tersebut terutama pada unsur-unsur pembentuk seni pertunjukan rakyat sisingaan yaitu pada unsur seni rupa dan busana pengusung, unsur widitra (karawitan) dan sinden, serta unsur gerak tari.

\section{DAFTAR PUSTAKA}

Arikunto, Suharsimi. (2006). Prosedur Penelitian Suatu Pendekatan Praktik. Jakarta: PT. Asdi Mahasatya. 
Koentjaraningrat. (1990). Pengantar IImu Antropologi. Jakarta: Rineka Cipta.

Mustofa, Bisri, dkk. (2010). Kamus Lengkap Sosiologi. Jogjakarta: Panji Pustaka 
